\title{
Petrogeochemistry of Amphibolites from Shivpura District Bhilwara, Rajasthan, India
}

\author{
Harel Thomas ${ }^{1}$ and Lalu Paudel ${ }^{2}$ \\ ${ }^{1}$ Department of Applied Geology, Dr. H.S.G. University, Sagar (MP), India \\ ${ }^{2}$ Central Department of Geology, Tribhuvan University, Kritipur, Kathmandu, Nepal \\ ${ }^{1}$ E-mail:-: harelthomas@yahoo.com
}

\begin{abstract}
Amphibolites are frequently observed in the medium- to high-grade metamorphic rocks of Shivpura. These amphibolites are the result of the metamorphism of pre-existing mafic igneous rocks under medium to high grade P-T conditions and consist essentially of hornblende-plagioclase-garnet-clinopyroxene-epidote-iron oxide. Geochemically, these orthoamphibolites are tholeiitic, show association with non-orogenic environment and shift to subalkaline derivatives with progressive differentiation. It is also clear that the parent magma for these rocks was highly evolved in nature. Paper records the petrography, geochemical characters and a probable origin of these amphibolites.
\end{abstract}

Keywords: Amphibolite petrology, geochemistry Shivapura, tholeiite, origin of amphibolite

\section{INTRODUCTION}

The area exposes rocks of the banded gneissic complex of the Proterozoic age (Buick et al. 2006). They predominantly include basic granulite, pelitic granulites and are surrounded by augen gneiss, migmatite and amphibolites, and constitute the main litho units of the gneissic complex (Fig.1) (Sharma 2003, Joshi et al. 1993, Thomas 1991, 1995, 2005a, 2005b, Thomas 2014, Thomas \& Sujata 2008, Thomas \& Vishwakarma 2009, 2011a, 2011b, Vishwakarma \& Thomas 2015).

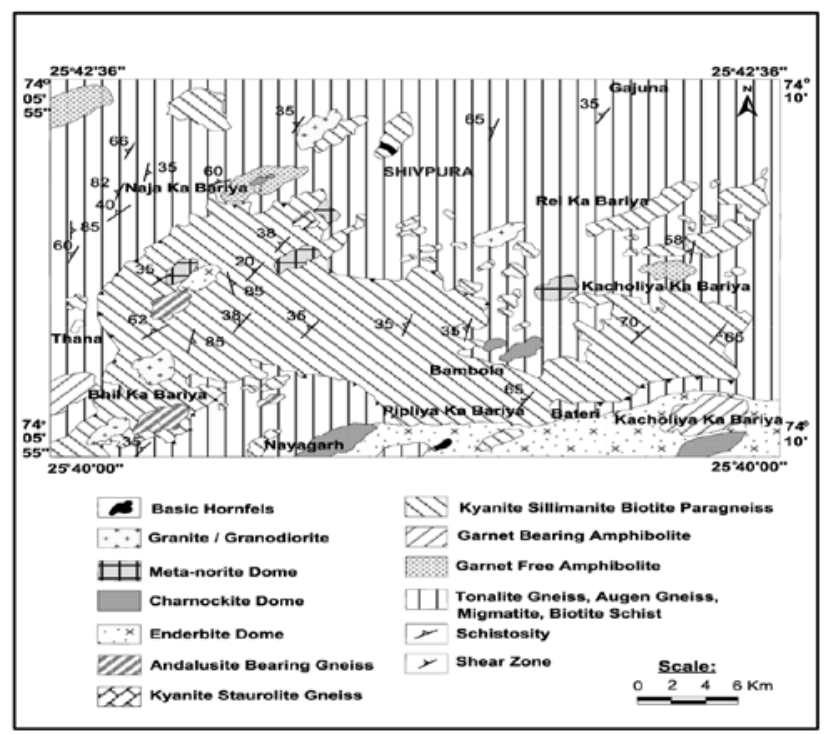

Fig. 1. A combined lithological and structural map of Shivpura, District-Bhilwara, Rajasthan (Thomas 2005).
The Amphibolite occurs as isolated bands varying in width from a few centimeters to 30 meter, and also as lensoid bodies within the para-gneiss. At places the amphibolites are mixed with gneisses to form migmatite on mesoscopic and megascopic scales. This mixed rock is characterized by a conspicuous schistosity due to the presence of equi- dimensional hornblende in varying amounts. The aim of this paper is to describe the petrography, chemical characters and a probable origin of these amphibolites.

\section{Petrography}

Amphibolite occurs as isolated bands varying in width from a few centimeters to 40 meter, and also as lensoid bodies within the paragneiss. At places the amphibolites are mixed with gneisses to form migmatites on mesoscopic and megascopic scales. This mixed rock is characterized by conspicuous schistosity due to the presence of equidimensional hornblende in varying amounts. This rock group consists of different assemblages. Therefore, on the basis of paragenesis the amphibolites can be divided into two major groups:

(a) Garnet-bearing amphibolite and

(b) Garnet-free amphibolite

Despite this difference in mineralogy and texture, their petrography is described together to avoid repetition.

\section{Megascopic Character}

The rock is medium- to coarse-grained and moderate to highly compact. Sometimes the rock contains fine laminations. Hornblende is the main constituent and is 
accompanied by plagioclase, garnet, quartz, feldspar and sphene, etc. Lineation due to preferred dimensional orientation of hornblende is often discernible.

\section{Microstructure/Texture}

Schistosity is distinct in hand specimens. Porphyroblastic texture is revealed by hornblende and also by garnet which are often sieved with hornblende, sphene and quartz (Plate 1AB). Symplectitic reaction rim also occurs due to the development of hornblende between clinopyroxene and plagioclase (Plate 1CD) or by the presence of garnet reaction rims between hornblende and plagioclase (Plate $2 \mathrm{AB}$ ). Epidote occasionally formed through the hydration reaction of plagioclase few sections (Plate $1 \mathrm{AB}$ ). Potash feldspar is generally perthitic and at times in large size to appear as a porphyroblast. In a few sections, granophyric intergrowth was also noticed. The different assemblages recorded in the rocks are:

\section{(a) Garnet-Bearing amphibolite}

I. Hornblende-garnet-diopside-plagioclaseepidote-quartz-K-feldspar-ilmenite-magnetite (Sample No.R87/225)

II. Hornblende-plagioclase-garnet$\mathrm{K}-\mathrm{feldspar}( \pm \mathrm{ep}$ idote $)-\mathrm{mag}$ netite (Sample No.R87/489)

\section{(b) Garnet-Free amphibolite}

I. Hornblende-epidote-plagioclase-quartz K-feldspar-sphene + zircon

(Sample No.R87/422)

II. Hornblende-diopside-plagioclase-Kfeldspar-quartz \pm epidote-rutile \pm ilmenite (Sample No.R87/329)

\section{Microscopic Description of Minerals}

\section{Hornblende}

Hornblende crystals are medium to coarse grained with the pleochroism.

$$
\begin{aligned}
& \Gamma=\text { light yellowish brown, } \\
& \mathrm{B}=\text { green } \\
& \mathrm{A}=\text { dark bluish green }
\end{aligned}
$$

Grains often show schiller structure due to the presence of opaque dust and streaks along the cleavage traces. Some laths are studded with several inclusions of quartz, ilmenite, epidote and plagioclase. Hornblende is commonly present in the garnet free and garnet bearing amphibolites.

The reaction rim of hornblende at the clinopyroxeneplagioclase interface (Plate 1CD), and the inclusions of small diopside crystals in hornblende suggest that these phases are possibly related by reaction such as:

$$
\begin{gathered}
\text { Clinopyroxene }+ \text { Plagioclase } \\
\text { Quartz }
\end{gathered} \mathrm{H}_{2} \mathrm{O}=\text { Hornblende }+
$$

The above reaction is a hydration reaction and thus indicative of retrograde metamorphism. This makes hornblende-plagioclase and hornblende - quartz as stable associations. However, at other places the hornblende plagioclase is incompatible. The two phases are separated by a rim of garnet. A possible reaction for this relationship is (Plate 2AB):

Hornblende + Plagioclase $=$ Garnet + Quartz $+\mathrm{H}_{2} \mathrm{O}$

This is certainly a prograde metamorphism reaction during granulite facies metamorphism.

\section{Garnet}

Equant crystals of garnet are rare. Fractured crystals with irregular outline are common (Plate $1 \mathrm{AB} \& 2 \mathrm{AB}$ ), suggesting post crystalline deformation. The garnets are brownish in coloured and occur as fresh granules and/ or as an aggregate at the hornblende/plagioclase contacts (Plate 2AB). The textural relation in the formation of garnet in the rock may suggest the following reaction:

Hornblende + Plagioclase $=$ Garnet + Quartz $+\mathrm{H}_{2} \mathrm{O}$

\section{Diopside}

Diopside is non-pleochroic but shows light pink or light green colour the crystals are embedded in hornblende or are rimmed by hornblende, against its contact with plagioclase (Plate 1C-D). At places epidote granules are also present near hornblende. However, at other places the clinopyroxene-plagioclase is incompatible. The probable reaction for this textural relationship is:

Diopside + Plagioclase $+\mathrm{H}_{2} \mathrm{O}=$ Hornblende \pm Quartz

Some clinopyroxene shows schiller structure.

\section{Plagioclase}

Plagioclase crystals are without any dimensional orientation. In a few sections, plagioclase is altered or kaolinized near the margins and the altered crystals show bent lamellae and mortar structure. The feature may indicate hydration of plagioclase during post crystalline deformation (cataclasis). Most grains are free of inclusions but at places plentiful epidote is found in the outer region of plagioclase contacting hornblende, which suggests the reaction:

$$
\text { Plagioclase }+\mathrm{H}_{2} \mathrm{O}=\text { Epidote }
$$

The anorthite percentage of the plagioclase varies from $\mathrm{An}_{32}$ to $\mathrm{An}_{47}$.

\section{Epidote}

Epidote occurs as defined idioblasts in columnar 
aggregates, associated with the hornblende or mica and sometimes seen flattened along them. It is usually associated with garnet. In one section it is showing myrmekite structure (Plate 1AB). The epidote is generally formed by the hydration reaction of plagioclase as follows:

\section{Quartz}

$$
\text { Plagioclase }+ \text { Calcite }=\text { Scapolite }
$$

Quartz is generally more sutured and shattered. The crystals show a high degree of deformation, as revealed by their elongation and undulose extinction.

\section{Sphene}

A large number of xenoblastic sphene crystals are seen in aggregate masses which are slightly flattened along the plane of schistosity. Rhomb shaped idioblasts are rather rare. Magnetite is always included within sphene. Sphene also contains inclusions of rutile. The possible reaction is:

$$
\mathrm{TiO}_{2}+\mathrm{CaCO}_{2}+\mathrm{SiO}_{2}=\mathrm{CaTiSiO}_{5}+\mathrm{CO}_{2}
$$

\section{Magnetite}

It is present either as minute inclusions with other minerals or as bigger isolated grains. Apatite, rutile, ilmenite and zircon are the other minor mineral constituents.

\section{Whole-rock geochemistry}

Analytical techniques

Eleven amphibolites samples were selected for geochemical study. Major and few trace elements were determined by ASS method, at the Wadia Institute of Himalaya Geology, Dehradun, U.P. now Uttarakhand Results (major oxides, norms, niggli values, and trace elements) of the eleven selected samples of amphibolites assemblages are presented in the Tables 1 and 2, respectively.

Table 1. Major element analyses (in wt \%) and trace element analyses (in ppm) values of amphibolites from

\begin{tabular}{|c|c|c|c|c|c|c|c|c|c|c|c|}
\hline S. No & R87/266 & R87/351 & R87/357 & R87/495 & R87/371 & R87/329 & R87/400 & R87/422 & R87/237 & R87/277 & R87/487 \\
\hline $\mathrm{SiO}_{2}$ & 59.98 & 63.67 & 64.6 & 60.90 & 49.84 & 66.40 & 50.68 & 61.81 & 65.51 & 56.20 & 60.90 \\
\hline $\mathrm{Al}_{2} \mathrm{O}_{3}$ & 13.62 & 14.14 & 14.4 & 14.14 & 14.93 & 13.62 & 15.71 & 14.14 & 13.62 & 14.40 & 14.70 \\
\hline $\mathrm{Fe}_{2} \mathrm{O}_{3}$ & 1.17 & 1.16 & 1.16 & 2.12 & 2.16 & 1.36 & 1.31 & 2.00 & 1.33 & 2.28 & 2.20 \\
\hline $\mathrm{FeO}$ & 7.97 & 6.23 & 4.84 & 7.33 & 8.16 & 4.64 & 8.08 & 6.26 & 6.12 & 9.11 & 7.50 \\
\hline $\mathrm{MgO}$ & 2.42 & 1.00 & 1.81 & 3.02 & 7.46 & 1.41 & 8.67 & 2.02 & 2.42 & 3.02 & 2.60 \\
\hline $\mathrm{CaO}$ & 6.17 & 5.60 & 4.48 & 4.48 & 11.22 & 7.29 & 10.65 & 6.16 & 3.64 & 7.29 & 5.60 \\
\hline $\mathrm{Na}_{2} \mathrm{O}$ & 3.00 & 2.40 & 2.00 & 2.00 & 3.40 & 0.80 & 2.00 & 1.40 & 2.20 & 2.20 & 2.20 \\
\hline $\mathrm{K}_{2} \mathrm{O}$ & 3.00 & 4.10 & 5.00 & 3.10 & 0.30 & 3.60 & 2.60 & 3.70 & 3.50 & 2.70 & 2.80 \\
\hline $\mathrm{MnO}$ & 0.11 & 0.08 & 0.06 & 0.11 & 0.12 & 0.04 & 0.14 & 0.95 & 0.10 & 0.15 & 0.10 \\
\hline $\mathrm{TiO}_{2}$ & 1.30 & 0.88 & 0.75 & 1.32 & 0.82 & 0.59 & 0.84 & 1.22 & 1.07 & 1.54 & 1.36 \\
\hline $\mathrm{P}_{2} \mathrm{O}_{5}$ & 0.00 & 0.07 & 0.07 & 0.07 & 0.78 & 0.25 & 0.13 & 0.15 & 0.08 & 0.36 & 0.20 \\
\hline Total & 98.74 & 99.33 & 99.16 & 98.59 & 99.19 & 100.01 & 100.80 & 99.61 & 99.59 & 99.25 & 100.16 \\
\hline \multicolumn{12}{|c|}{ Trace elements } \\
\hline $\mathrm{Cu}$ & 187 & 191 & 160 & 37 & 200 & 165 & 187 & 194 & 37 & 70 & 160 \\
\hline Co & 11 & 008 & 86 & 08 & 17 & 86 & 13 & 07 & 07 & 11 & 10 \\
\hline $\mathrm{Ni}$ & 22 & 20 & 20 & 14 & 55 & 18 & 53 & 13 & 16 & 17 & 32 \\
\hline $\mathrm{Li}$ & 19 & 9 & 15 & 19 & 13 & 11 & 08 & 19 & 24 & 19 & 20 \\
\hline $\mathrm{Rb}$ & 98 & 141 & 121 & 116 & 0 & 191 & 53 & 101 & 136 & 113 & 106 \\
\hline $\mathrm{Sr}$ & 222 & 157 & 281 & 260 & 248 & 354 & 260 & 182 & 236 & 257 & 307 \\
\hline $\mathrm{V}$ & 108 & 81 & 69 & 120 & 216 & 75 & 180 & 240 & 115 & 243 & 138 \\
\hline $\mathrm{Zn}$ & 141 & 148 & 131 & 114 & 147 & 115 & 128 & 141 & 107 & 164 & 126 \\
\hline
\end{tabular}
Shivpura, District Bhilwara, Rajasthan 
Table 2. CIPW norms and Niggli values of amphibolites from Shivpura, Bhilwara, Rajasthan

\begin{tabular}{|c|c|c|c|c|c|c|c|c|c|c|c|}
\hline Sam. No & $\begin{array}{l}\text { R287/ } \\
266\end{array}$ & \begin{tabular}{|l} 
R287 \\
/351
\end{tabular} & $\begin{array}{l}\text { R287 / } \\
\mathbf{3 5 7}\end{array}$ & $\begin{array}{l}\text { R287 } \\
\text { /495 }\end{array}$ & $\begin{array}{l}\text { R287 } \\
\text { /371 }\end{array}$ & $\begin{array}{l}\text { R287 } \\
\text { /329 }\end{array}$ & \begin{tabular}{|l|} 
R287 \\
/400
\end{tabular} & $\begin{array}{l}\text { R287 } \\
\text { /422 }\end{array}$ & $\begin{array}{l}\text { R87/ } \\
237\end{array}$ & $\begin{array}{l}\text { R287/ } \\
277\end{array}$ & $\begin{array}{l}\text { R287/ } \\
487\end{array}$ \\
\hline Quartz & 12.32 & 19.08 & 20.03 & 19.28 & --- & 30.48 & -- & 21.83 & 24.28 & 11.03 & 18.53 \\
\hline Orthoclase & 17.74 & 24.24 & 29.58 & 18.35 & 1.78 & 21.29 & 15.57 & 21.91 & 20.68 & 15.96 & 16.57 \\
\hline Albite & 25.36 & 20.28 & 16.93 & 16.93 & 28.72 & 6.76 & 16.77 & 11.84 & 18.60 & 18.60 & 18.60 \\
\hline Anorthite & 14.79 & 15.65 & 15.48 & 20.38 & 24.58 & 22.88 & 26.13 & 21.29 & 16.90 & 20.68 & 21.91 \\
\hline Diopside & 13.05 & 09.98 & 5.06 & 1.44 & 21.61 & 9.56 & 21.18 & 6.79 & 0.97 & 19.29 & 3.96 \\
\hline Hypersthene & 11.32 & 06.58 & 8.78 & 16.55 & 5.54 & 5.38 & -- & 9.72 & 14.11 & 14.40 & 14.38 \\
\hline Olivine & - & - & - & - & 10.57 & - & 17.40 & --- & --- & --- & ---- \\
\hline magnetite & 1.69 & 1.67 & 1.69 & 3.09 & 3.13 & 1.97 & 1.90 & 2.90 & 1.93 & 3.32 & 3.20 \\
\hline Ilmenite & 2.46 & 1.67 & 1.41 & 2.51 & 1.55 & 1.12 & 1.67 & 2.33 & 2.04 & 2.93 & 2.58 \\
\hline Apatite & - & 0.17 & 0.17 & 0.71 & 1.85 & 0.60 & 0.27 & 0.37 & -- & 0.84 & 0.47 \\
\hline \multicolumn{12}{|c|}{ Niggle Values } \\
\hline $\mathrm{Al}$ & 26.15 & 30.96 & 32.57 & 28.39 & 20.00 & 27.59 & 20.64 & 29.26 & 30.83 & 24.88 & 23.94 \\
\hline Alk & 15.70 & 18.36 & 19.72 & 13.34 & 7.92 & 12.41 & 8.02 & 13.05 & 16.76 & 11.30 & 13.67 \\
\hline $\mathrm{C}$ & 21.53 & 22.29 & 18.20 & 16.35 & 27.33 & 31.57 & 25.03 & 23.17 & 14.98 & 22.89 & 20.93 \\
\hline $\mathrm{Mg}$ & 0.32 & 0.20 & 0.35 & 0.37 & 0.56 & 0.30 & 0.62 & 0.31 & 0.37 & 0.32 & 0.33 \\
\hline Fm & 36.62 & 28.38 & 29.50 & 41.93 & 44.72 & 28.42 & 46.31 & 34.52 & 37.98 & 40.92 & 41.46 \\
\hline $\mathrm{Si}$ & 195.43 & 236.65 & 248.37 & 207.51 & 113.35 & 268.48 & 113.01 & 217.13 & 251.66 & 164.81 & 212.54 \\
\hline $\mathrm{Ti}$ & 3.17 & 2.46 & 2.14 & 3.38 & 1.40 & 1.80 & 1.41 & 3.17 & 3.09 & 3.39 & 3.57 \\
\hline $\mathrm{P}$ & - & 0.11 & 0.12 & 0.10 & 0.75 & 0.43 & 0.11 & 0.22 & 0.13 & 0.45 & 0.30 \\
\hline K & 0.40 & 0.53 & 0.62 & 0.51 & 0.05 & 0.75 & 0.46 & 0.36 & 0.51 & 0.45 & 0.46 \\
\hline
\end{tabular}

The compositional ranges for major elements are displayed in Harker variation diagrams (Fig. 2). The $\mathrm{SiO}_{2}$ contents of amphibolites ranges from 49.84 to 66.40 percent averaging at 60.04 percent. With increasing $\mathrm{SiO}_{2}$ content, $\mathrm{Al}_{2} \mathrm{O}_{3}, \mathrm{FeO}$ and $\mathrm{MgO}$ decreases markedly from 13.62 to 15.71 percent, 4.64 to 9.11 percent and 1.00 to 8.67 percent respectively. The $\mathrm{K}_{2} \mathrm{O}$ varies from 0.30 to

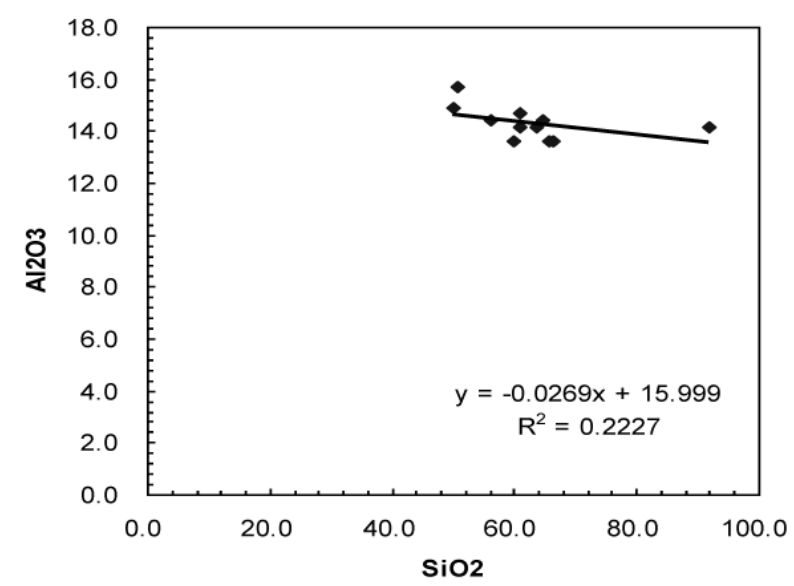

5.00 percent and averages at 3.13 percent while $\mathrm{Na}_{2} \mathrm{O}$ ranges from 0.80 to 3.40 percent with an average of 2.15 percent. The $\mathrm{CaO}$ content ranges from 3.64 to 11.22 percent averaging at 6.60 percent. The $\mathrm{K}_{2} \mathrm{O}, \mathrm{Na}_{2} \mathrm{O}$ and $\mathrm{CaO}$ contents are seem to be good correlated with $\mathrm{SiO}_{2}$ (Fig. 2).

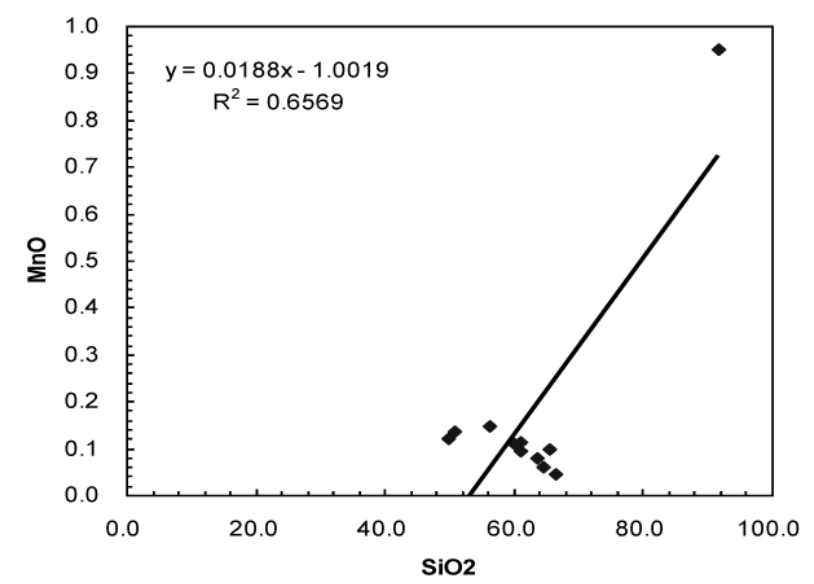



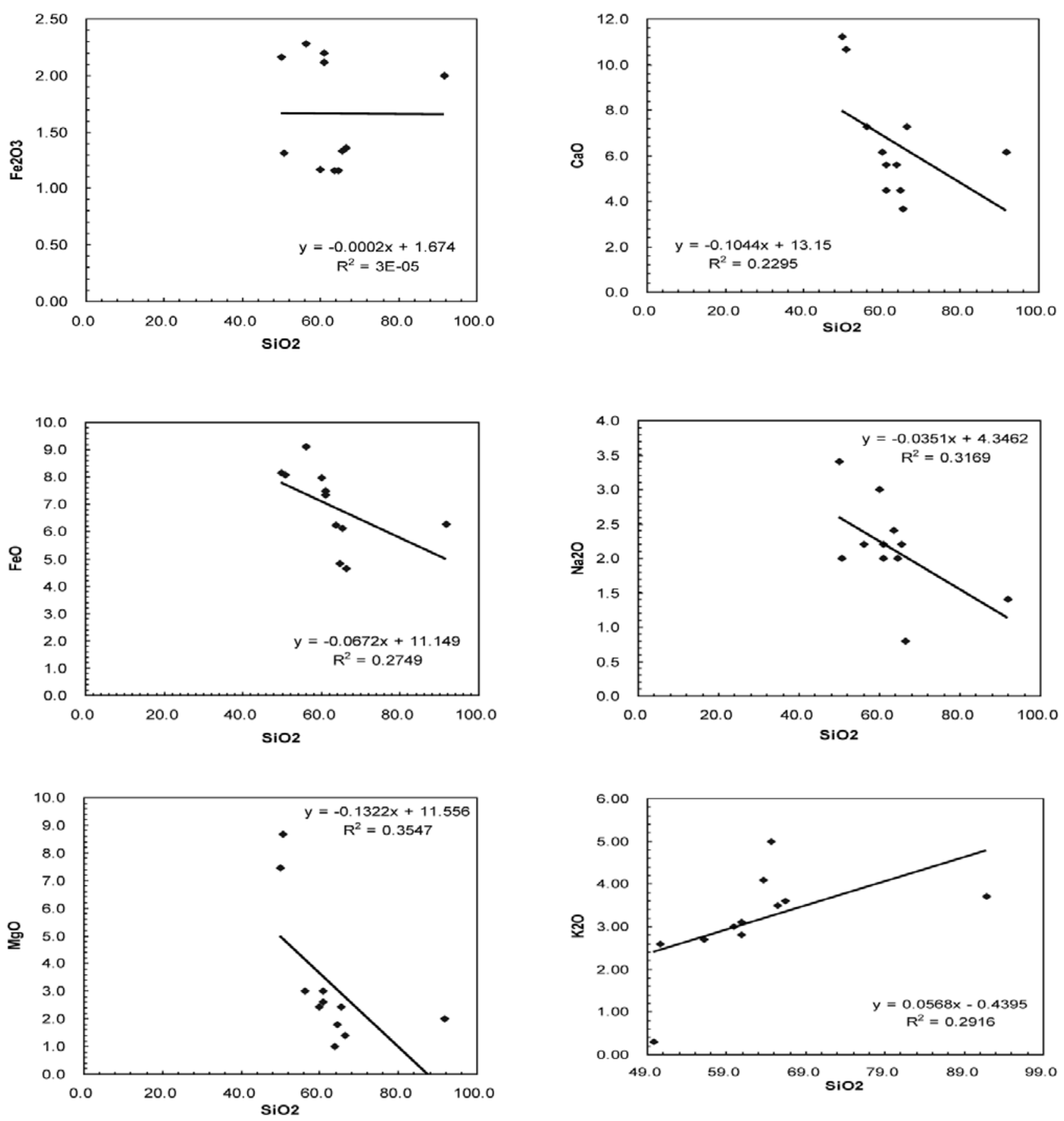

Fig. 2. Harker variation diagram for amphibolite from Shivpura, Rajasthan, India

The Niggli's 100mg-c-(al-alk), Leake (1964) diagram (Fig. 3), shows that all samples fall within the late basic igneous rocks field. Similarly, the Niggli's "c" and (alalk) diagram (Fig. 4) supports an igneous parentage for the amphibolites. On the basis of silica-alkalis $\left(\mathrm{SiO}_{2}\right.$ vs. $\mathrm{K}_{2} \mathrm{O}+\mathrm{Na}_{2} \mathrm{O}$ ) discrimination diagram (Fig. 5), (Irvine \& Baragar 1971), clearly indicates that all samples lie within the sub-alkaline field. 


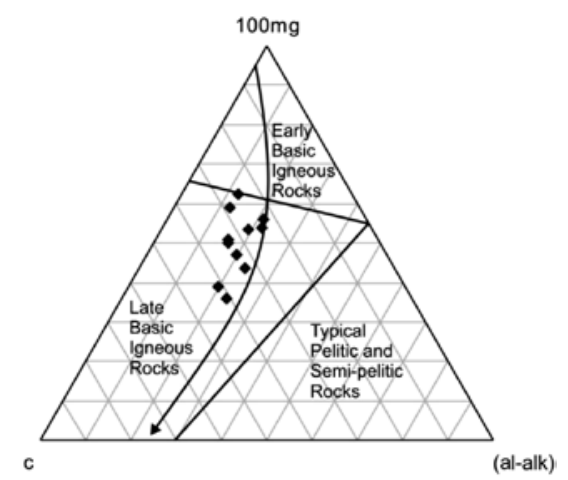

Fig. 3. The $100 \mathrm{mg}-\mathrm{c}-($ al-alk) of the selected eleven amphibolite rock samples from Shivpura area, District Bhilwara, Rajasthan.

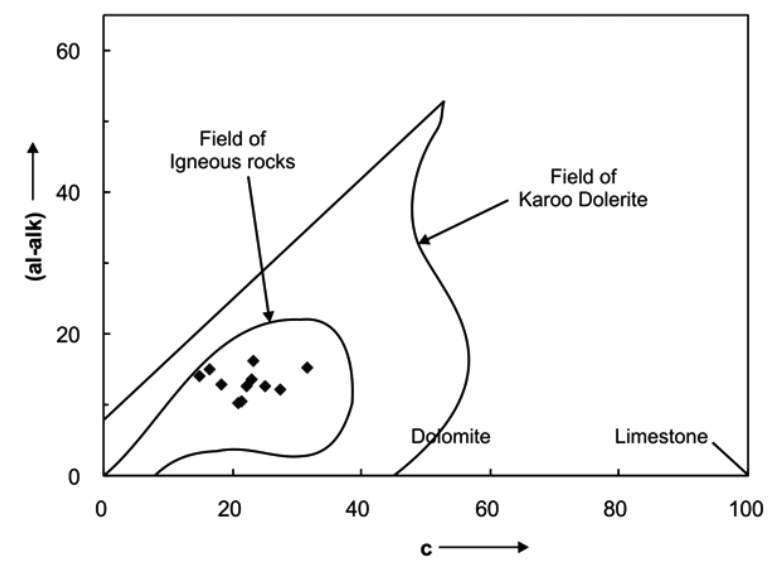

Fig. 4. The silica-alkali discrimination plot of Irvin and Baragar (1971) for the selected eleven amphibolite rock from Shivpura area, District Bhilwara, Rajasthan.

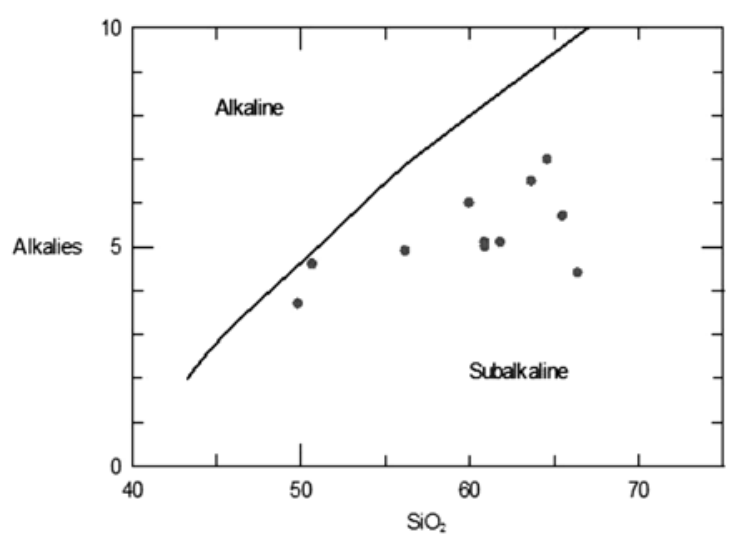

Fig. 5. The silica-alkali discrimination plot of Irvin and Baragar (1971) for the selected eleven amphibolite rock from Shivpura area, District Bhilwara, Rajasthan.

In order to differentiate the field of calc-alkaline and tholeiitic basalts, the AFM diagram (Fig. 6) (Irvine \& Baragar 1971) as well as, the $\mathrm{FeO}^{\mathrm{T}} / \mathrm{MgO}$ and $\mathrm{SiO}_{2}$ diagram (Fig. 7), (Miyashiro 1974), show their tholeiitic nature.

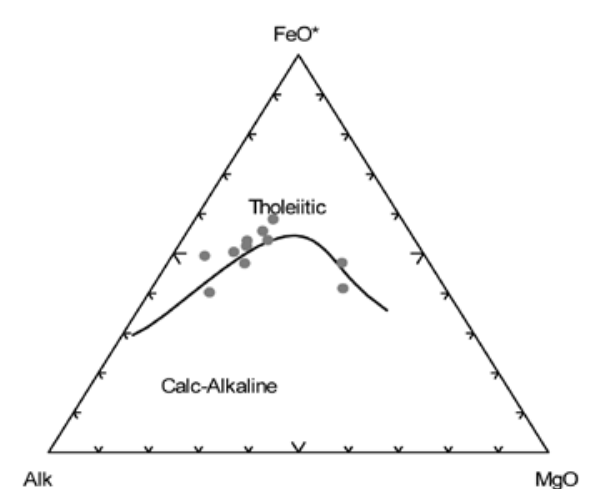

Fig. 6 The AFM discrimination plot of Irvin and Baragar (1971) for the selected eleven amphibolite rocks from Shivpura area, District Bhilwara, Rajasthan.

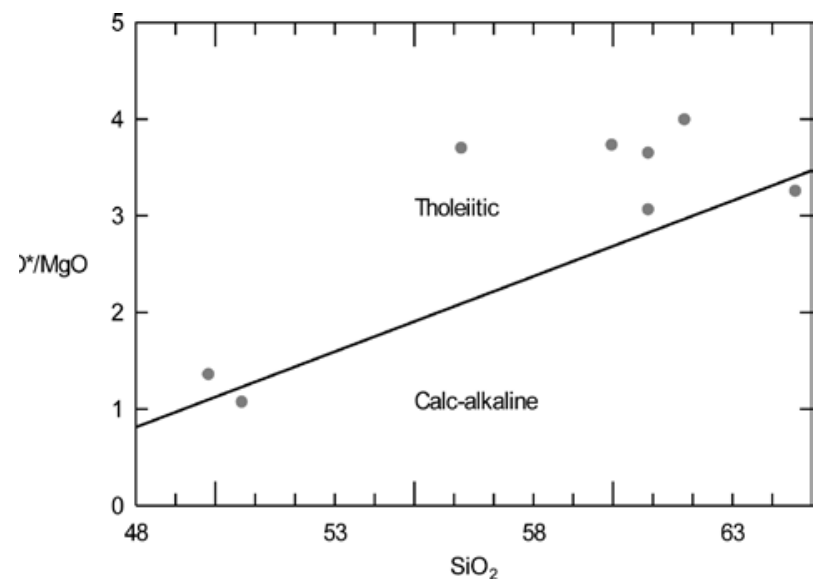

Fig. 7. The plot between $\mathrm{SiO2}$ versus FeOT/MgO of Miyashiro (1974) for the selected eleven amphibolite rock from Shivpura area, District Bhilwara, Rajasthan.

The diagram of (Fe $\left.{ }^{\mathrm{T}}+\mathrm{Ti}\right)-\mathrm{Al}-\mathrm{Mg}$, (Fig. 8), (Jenson \& Pyke 1982), clearly indicates that the samples fall in the tholeiitic field.

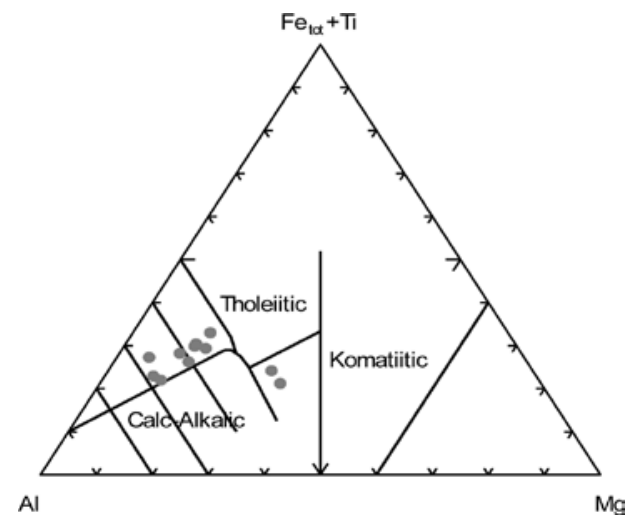

Fig. 8. The $(\mathrm{FeT}+\mathrm{Ti})-\mathrm{Al}-\mathrm{Mg}$ discrimination plot of Jenson and Pyke, (1982) for the selected eleven amphibolite rock from Shivpura area, District Bhilwara, Rajasthan. 


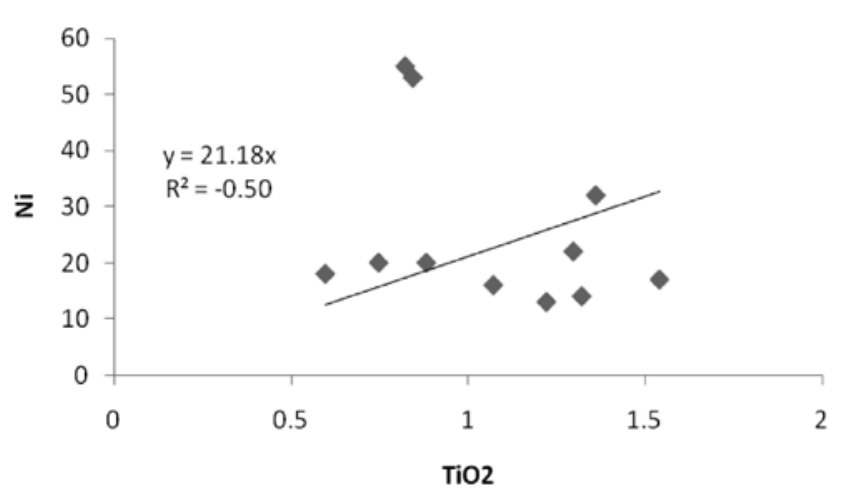

Fig. 9. Plot of Ni ppm vs $\mathrm{TiO} 2 \mathrm{wt} \%$
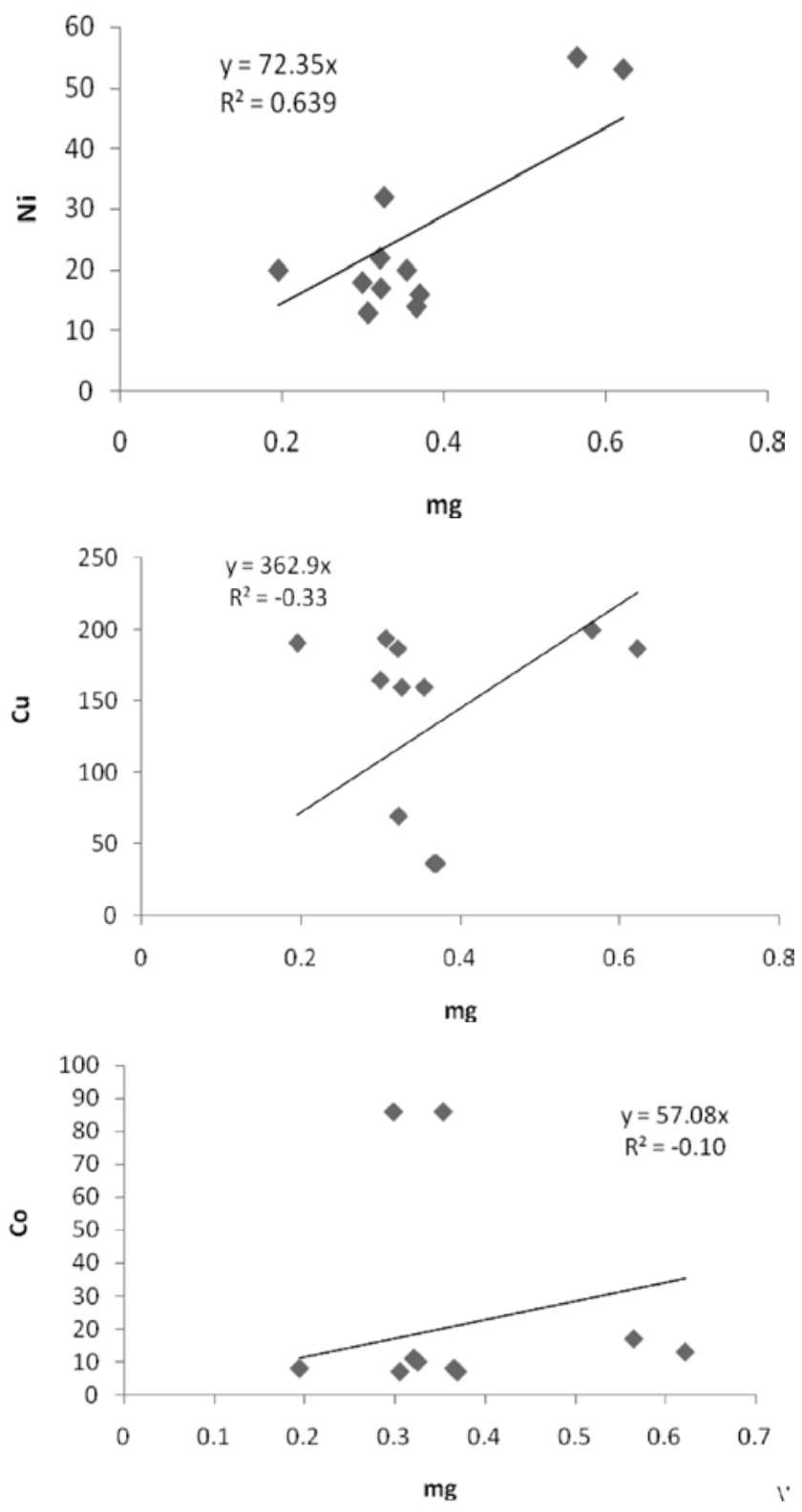

Fig. 10. Niggle mg vs Ni, $\mathrm{Cu}$ and $\mathrm{Co}$ after Leake (1964)
A negative correlation of $\mathrm{TiO} 2 \mathrm{wt} \%$ with $\mathrm{Ni}$ ppm (Fig. 9) is observed in mafic igneous rocks. Plots of Niggli mg vs $\mathrm{Ni}, \mathrm{Co}, \mathrm{Cu}$ (Fig. 10) define igneous fractionation as Leake (1964) suggest that positive correlation of mg with $\mathrm{Ni}$ indicates igneous fractionation. But with $\mathrm{Co}$ it show negative correction because cobalt does not vary with differentiation so much as $\mathrm{Ni}$ in most basic rocks (walker et al. 1960).

It can be thus concluded that tholeiite has been the parent composition of amphibolite. The presence of relic laths of plagioclase in some amphibolites along with these chemical discrimination diagrams supports orthometamorphic origin for the amphibolites of the area. Still REE is required in support of possible source of origin of these amphibolites which will be cover in future studies.

\section{CONCLUSION}

On the basis of the above discussion, the following conclusions can be draw:

i) The present amphibolites occurring as isolated bands varying in width from a few centimeter to 40 meter, and also as lensoid bodies within the para-gneiss, and result of metamorphism of pre-existing mafic igneous rocks like gabbroids (gabbro/dolerite) under medium to high grade P-T conditions.

ii) The mineralogy of the amphibolites which include hornblende, epidote, garnet, albite etc appears to be derived from original calcic plagioclasepyroxene. Alteration of pyroxene (relicts) is also the concurrent effects.

iii) The chemical characters of these amphibolites can be compared with that of the other known amphibolites. Diagrams and their interpretations indicate its igneous nature (orthotype) and affinity with sub-alkaline basalt whose composition was akin to tholeiites. It is also clear that the parent magma for these rocks was highly evolved in nature.

\section{ACKNOWLEDGEMENTS}

The author (HT) is thankful to Head, Department of Applied Geology and Director, Wadia Institute of Himalayan Geology, Dehradun for providing necessary facilities to carry out this research work. 
PLATE - 1
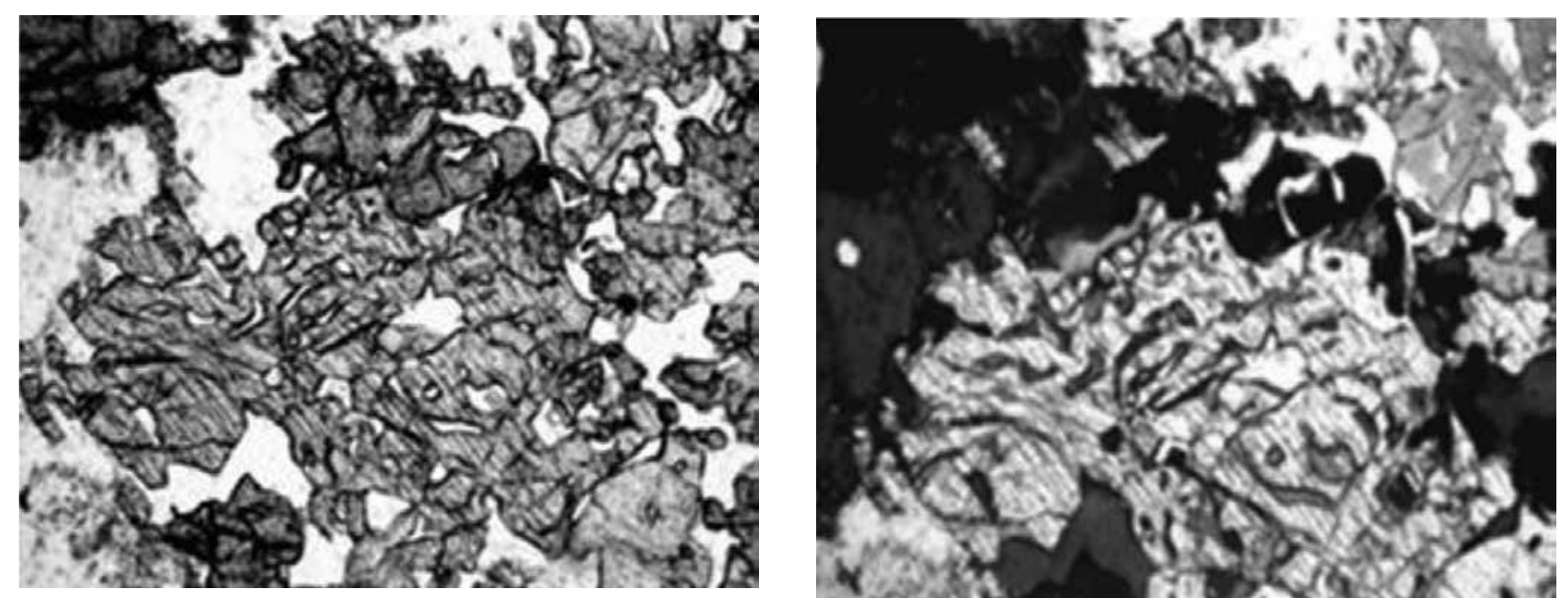

$1 \mathrm{AB}$ Development of epidote, which might have been formed through the hydration reaction of plagioclase.

Plagioclase $+\mathrm{H} 2 \mathrm{O}=$ Epidote

Also notice the garnet having irregular out line. (Sample No. R87/225)
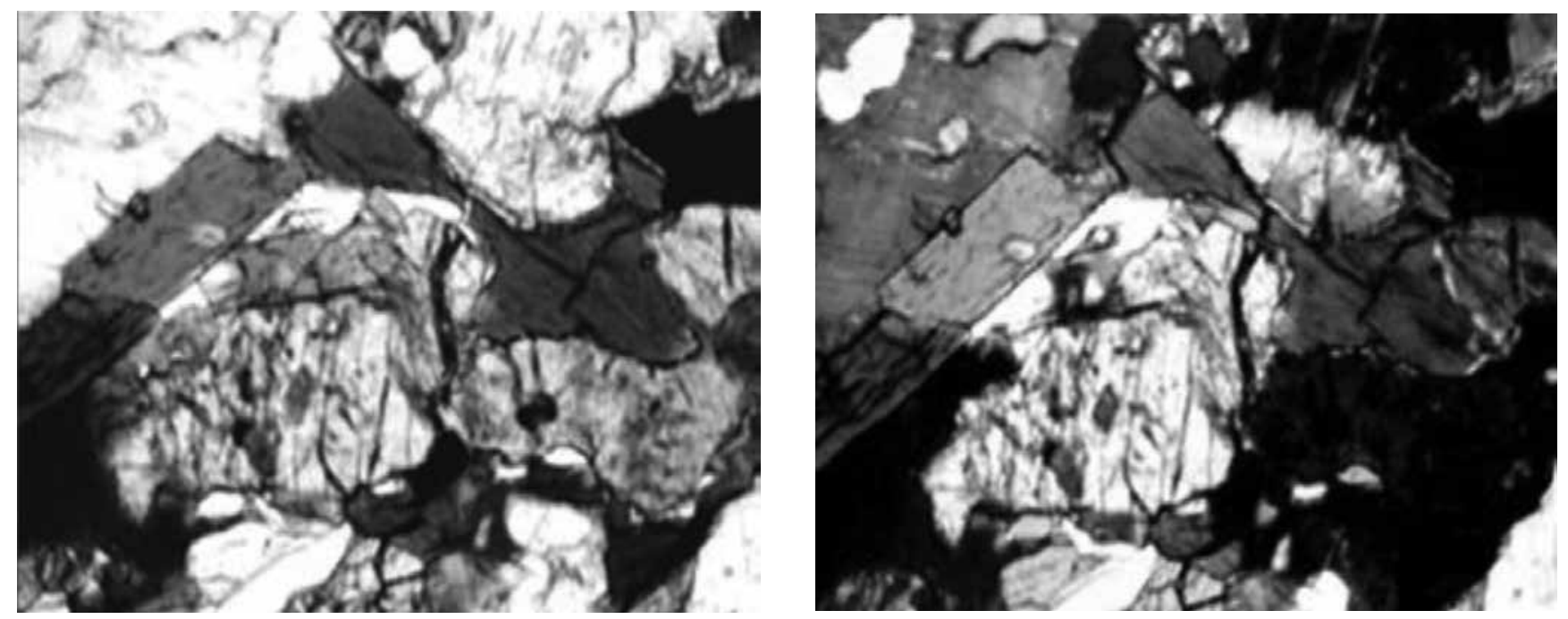

1CDRim of hornblende around clinopyroxene against its contact with plagioclase indicates towards the reaction: Clinopyroxene + Plagioclase $+\mathrm{H} 2 \mathrm{O}=$ Hornblende + Quartz

Notice the iron leaching in clinopyroxene. (Sample No. R97/422) 
PLATE - 2
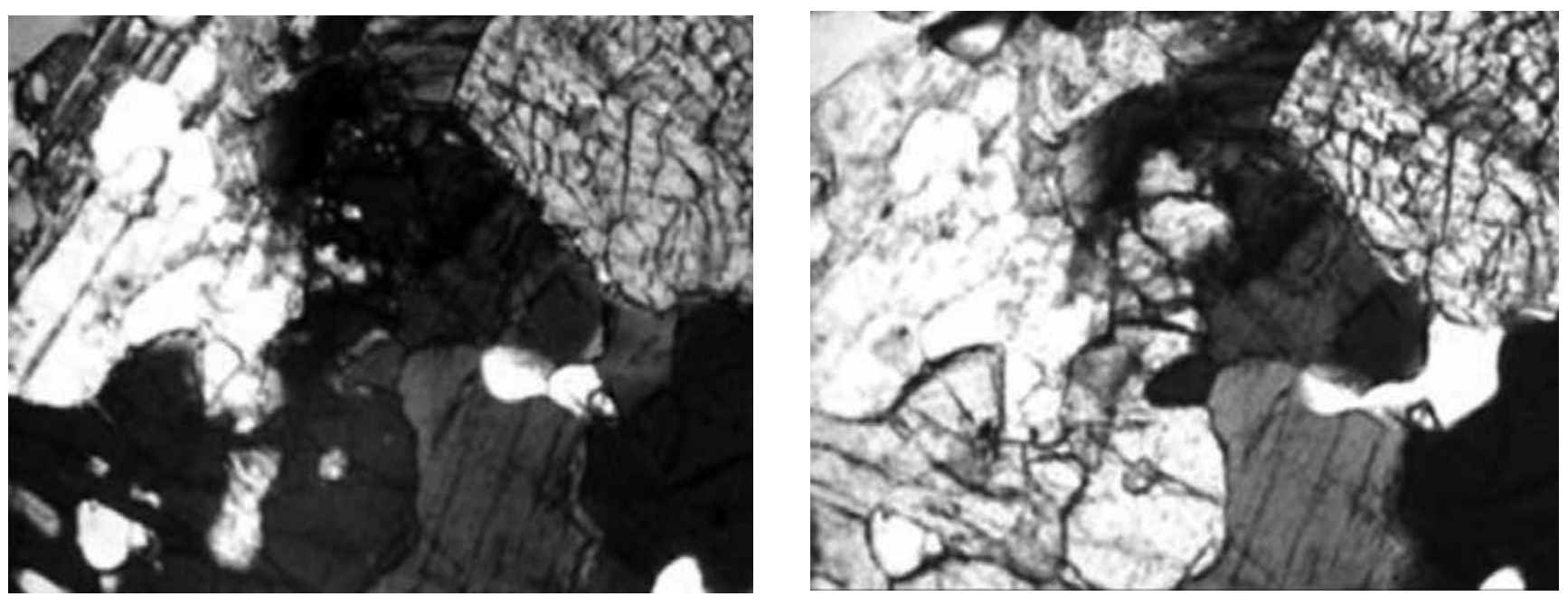

2AB Clinopyroxene rimed by hornblende and hornblende itself rimed by garnet against its contact with plagioclase, suggests the reaction:

Clinopyroxene + Plagioclase $+\mathrm{H}_{2} \mathrm{O}=$ Hornblende + Quartz

Followed by

Hornblende + Plagioclase $=$ Garnet + Quartz $+\mathrm{H}_{2} \mathrm{O}($ Sample No.R87/329)
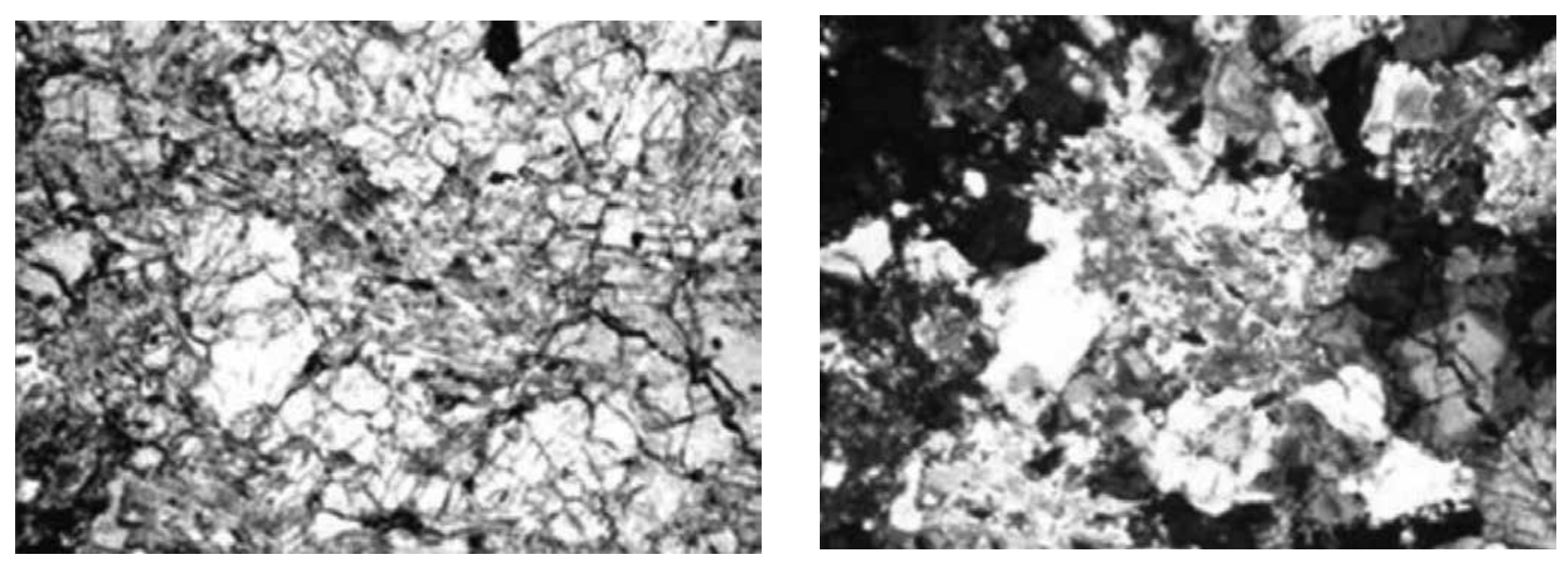

2CD - Replacement of plagioclase by epidote through the reaction:

Plagioclase $+\mathrm{H}_{2} \mathrm{O}=$ Epidote

Also notice the zoning in epidote. (Sample No.R87/302) 


\section{REFERENCES}

Buick, I.S., Allen, C., Pandit, M., Rubatto, D., Hermann, J. 2006. The Proterozoic magmatic and metamorphic history of the Banded Gneissic complex, central Rajasthan, India: LA-ICP-Ms $\mathrm{U}-\mathrm{Pb}$ ziron constraints. Precambrian Res.151: 119-142.

Irvine, T.N., Baragar, W.R.A. 1971. A guide to the chemical classification of the common rocks. Can. Jour. Earth Sci. 8: 523-548.

Jenson, L.S., Pyke, D.R. 1982. Komatites in the Ontario portion of the Abitibi Belt. In: N.T. Arndt and E.G. Nisbet (eds.), Komatites. London, Allen and Unwin. 147-158.

Joshi, M., Thomas, H., Sharma, R.S. 1993. Granulite facies metamorphism in the Archaean gneiss complex from North-Central Rajasthan. Proc. Nat. Acad. Sci. India 63 (A), I: 167-187.

Leake, B.E. 1964. The chemical distinction between para and ortho amphibolite. Jour. Petrol. 5: 238-254.

Miyashiro, A. 1974. Volcanic rock series in island arc and active continental margins. Amer. Jour. Sciences 274: 321-355.

Pearce, J.A., Harris, N.B.W., Tindle, A. G. 1984. Trace element discrimination diagrams for the tectonic interpretation of granitic rocks. Jour. Petrol. 25: 956-983.

Sharma, R.S. 2003. Evolution of Proterozoic fold belts of India: A case of the Aravalli Mountain Belt of Rajasthan, NW India. Geol. Soc. India., Mem. 52: 145-62.

Thomas, H. 1991. Petrographic study and Petrogenesis of the Precambrian rocks around Thana, District Bhilwara Rajasthan. Unpublished Ph.D. thesis (BHU), pp. 321

Thomas, H. 1995. Pressure Temperature considerations for granulite from Thana Gyangarh, District - Bhilwara, Rajasthan: Implication for crustal evolution. In: R.K. Srivastava and R. Chandra (eds.), Magmatism in relation to Divers Tectonic Setting. Oxford and IBH Publishing Com. Pvt. Ltd., pp.439- 456.
Thomas, H. 2005a. Polymetamorphism in the Archaean Gneiss Complex of Shivpura Gyangarh, District Bhilwara, Rajasthan. In: H. Thomas (ed.), Granulite facies metamorphism and Crustal Evolution., Atlantic publishers \& Distributors, New Delhi. pp.120-146.

Thomas, H. 2005b. Mineralogy and Mineral Chemistry of the Meta-Norite from Shivpura, District Bhilwara, Rajasthan. International Conference on Precambrian continental Growth \& Tectonism (PCGT) (ed. R. Chandra et al.), pp 209-212.

Thomas, H., Sujata, S. 2008. Petrology and Reaction texture of the Metanorites from Shivpura, District Bhilwara, Rajasthan. In: R. K. Srivastava, C. Sivaji and N. V. Chalapathi Rao (Eds.), Indian Dykes: Geochemistry, Geophysics and Geochronology. Narosa Publishing House Pvt. Ltd., New Delhi. pp.571-587.

Thomas, H., Vishwakarma, N. 2009. Petrochemical Studies of metanorite from Asind district Bhilwara, Rajasthan, India. In: $2^{\text {nd }}$ International Conference on Precambrian continental growth and Tectonism. pp.104-108.

Thomas, H., Vishwakarma, N. 2011. Geochemical Characters of Amphibolites from Asind District Bhilwara, Rajasthan, India. Asian Journal of Chemistry 25(12): 5433-5440.

Thomas, H., Vishwakarma, N. 2011. Petrochemical studies of amphibolites from Kirimal district Bhilwara, Rajasthan, Indian Memoir of the Geological Society of India No. 77, pp. 559-571

Vishwakarma, N., Thomas, H. 2015. Petrographic and geochemical characteristics of Charnockite from Asind, District Bhilwara, Rajasthan: Implication for its origin. Journal of applied geochemistry.

Walker, K.R., Joplin, G.A, Lovering, J.F., Green, R. 1960. Metamorphic and metasomatic convergence of basic igneous rocks and lime-magnesis sediments of the Precambrian of North- Western Queensland. Jour. Geol. Soc. Australia 6: 149178. 